\title{
KAJIAN SIFAT ENJINIRING PUREE WORTEL (Daucus carrota L.)
}

\section{(Study of Engineering Properties of Carrot Puree (Daucus carrota L.))}

\author{
Dian Purbasari ${ }^{1 *}$, Nanda Ikhtiar Muti1) \\ ${ }^{1)}$ Program Studi Teknik Pertanian Universitas Jember \\ Email Korespondensi: nandaikhtiarm@gmail.com
}

\begin{abstract}
The Post-harvest processing of carrots in Indonesia is still limited to being processed into the main ingredients of soup or vegetable of cap cay and sometimes blended to drink as juice and currently, there are still trying to make flour from carrots. This study uses a Complete Randomized Design (RAL) with two factors, namely the comparison of carrots and water and the length of grinding time. The measurement stages of technical properties begin from the preparation of raw materials, washing, cutting, purification, then measured of technical properties. The technical properties measured are viscosity, total solids, density, color, and thermal conductivity. The comparison of carrots and water used are 3:1 (450 gr:150 ml), 2:1 (400 gr:200 ml), and 1:2 (200 gr:400 ml) for a long time period of 150 seconds, 210 seconds, and 270 seconds. The Data analysis using two-way ANOVA statistical test with two factors that affect the comparison of carrots and water and length of life. Viscosity values range from $1697.78 \mathrm{cP}$ to $4661.44 \mathrm{cP}$. The total value of solids ranges from $3.11 \%$ to $7.20 \%$. Density values range from $1,004 \mathrm{~g} / \mathrm{ml}$ to $1,015 \mathrm{~g} / \mathrm{ml}$. The $\mathrm{L}$ color index value ranges from 34.33 to 42.77 . Color index values range from -1.06 to 6.44 . The color index value $b$ ranges from 12.65 to 26.95 . Thermal conductivity values range from $0.577 \mathrm{~W} / \mathrm{m}$.K to $0.682 \mathrm{~W} / \mathrm{m}$.K. The more proportions of carrots in a puree solution, the higher of viscosity value, total solids, density, and color indexes $\mathrm{L}$, a, and $\mathrm{b}$. While the value of thermal conductivity does not affect the comparison of carrots and water. At purification, time treatment does not affect solid total values, color index values $\mathrm{L}$, a, and b. However, it affects the density and viscosity value of carrot puree. The longer the milling time, the greater the viscosity value and density.
\end{abstract}

Keywords: engineering properties, carrots, two-way anova, puree

\begin{abstract}
ABSTRAK
Pengolahan wortel pasca panen di Indonesia masih sebatas diolah menjadi bahan utama sup atau sayur cap cay dan kadang diblender untuk diminum sebagai jus dan saat ini masih ada yang mencoba membuat tepung dari wortel. Penelitian ini menggunakan metode Rancangan Acak Lengkap (RAL) dengan dua faktor yaitu perbandingan wortel dan air serta lama waktu penggilingan. Tahapan pengukuran sifat keteknikan yaitu dimulai dari penyiapan bahan baku, pencucian, pemotongan, pemurnian, kemudian dilakukan pengukuran sifat keteknikan. Sifat keteknikan yang diukur adalah viskositas, total padatan, densitas, warna, dan konduktivitas termal. Perbandingan wortel dan air yang digunakan masing-masing adalah 3: 1 (450 gr: $150 \mathrm{ml}), 2: 1$ (400 gr: $200 \mathrm{ml}$ ), dan 1: 2 (200 gr: $400 \mathrm{ml}$ ) untuk lama waktu pemakaian yaitu 150 detik, 210 detik, dan 270 detik. Analisis data menggunakan uji statistik ANOVA dua arah dengan dua faktor yang mempengaruhi yaitu perbandingan wortel dan air serta lama waktu pakai. Nilai viskositas berkisar antara $1697,78 \mathrm{cP}$ hingga $4661,44 \mathrm{cP}$. Nilai total padatan berkisar antara 3,11\% sampai 7,20\%. Nilai kepadatan berkisar dari 1,004 g / ml hingga 1,015 g/ ml. Nilai indeks warna L berkisar antara
\end{abstract}


34,33 hingga 42,77. Nilai indeks warna berkisar antara $-1,06$ hingga 6,44 . Nilai indeks warna $b$ berkisar antara 12,65 hingga 26,95. Nilai konduktivitas termal berkisar antara 0,577 W / m.K hingga 0,682 W / m.K. Semakin banyak proporsi wortel dalam larutan haluskan, semakin tinggi nilai viskositas, total padatan, massa jenis, dan indeks warna $\mathrm{L}$, a, dan b. Sedangkan nilai konduktivitas termal tidak berpengaruh terhadap perbandingan wortel dan air. Pada perlakuan waktu pemurnian tidak berpengaruh terhadap nilai total solid, nilai indeks warna $L$, a, dan $b$. Namun, hal itu mempengaruhi nilai densitas dan viskositas puree wortel. Semakin lama waktu penggilingan, semakin besar nilai viskositas dan densitasnya.

Kata kunci: sifat enjiniring, wortel, anova dua arah, puree

\section{PENDAHULUAN}

Wortel (Daucus carrota L.) merupakan jenis sayuran umbi yang biasanya berwarna jingga ataupun orange dengan tekstur serupa kayu. Bagian yang dapat diolah sebagai bahan pangan dari wortel adalah bagian umbi atau akarnya (Mehrir, 2012: 12). Berdasarkan statistik pertanian produksi tanaman sayuran dan buah-buahan semusim di Indonesia (Badan Pusat Statistik, 2017) luas areal panen wortel nasional mencapai 30.564 hektar dengan rata-rata jumlah panen 17,53 ton/hektar dan total panen nasional sebanyak 537.341 ton. Banyaknya hasil panen tersebut tidak sebanding dengan inovasi pada pengolah pascapanen dari wortel tersebut. Padi merupakan bahan pangan utama bangsa Indonesia. Umumnya wortel hanya dijadikan sebagai bahan utama pada sayur sup, diblender menjadi minuman jus, ataupun sebagai campuran capcay maupun sayur tumis. Hal ini dikarenakan sebagian masyarakat Indonesia tidak terlalu menyukai wortel untuk dikonsumsi akibat dari teksturnya yang keras berserat dan butuh waktu memasak yang lumayan lama supaya teksturnya menjadi lunak. Berdasarkan pernyataan tersebut perlu adanya analisis terhadap sifat enjiniring puree wortel pada beberapa perlakuan tambahan. Tujuannya ialah untuk mengetahui sifat enjiniringnya, sehingga mempermudah dalam menentukan proses pengolahan yang tepat dan optimal terhadap wortel dalam bentuk puree.

\section{METODE PENELITIAN}

\section{Alat dan Bahan}

Alat yang digunakan dalam penelitian diantaranya yaitu Viscometer, Color Reader CR-10, Timbangan Digital, Eksikator, Blender, Gelas Ukur, Gelas Beaker, Cawan Sampel, Penjepit, Baskom, Pipet, Kertas Label, dan Kamera Smartphone.

Bahan penelitian menggunakan wortel local yang didapat dari Pasar Kreongan, Patrang, Kabupaten Jember.

\section{Tahapan Penelitian \\ Persiapan Bahan Baku}

Bahan baku yang dibutuhkan untuk penelitian yaitu wortel local yang didapat dari Pasar Kreongan, Patrang, Kabupaten Jember.

\section{Pencucian dan Pengupasan}

Wortel yang telah diperoleh dan telah dipilih yang baik atau tidak cacat, dicuci terlebih dahulu untuk memastikan benar-benar bersih dari kotoran yang masih menempel pada kulit wortel. Pencucian dilakukan dengan menyikat kulit wortel sambil di aliri air. Setelah dicuci wortel kemudian dikupas untuk menghilangkan kulit terluarnya.

\section{Pemotongan Wortel}

Pemotongan wortel dilakukan bertujuan untuk mengecilkan ukuran wortel agar mudah diolah menjadi puree dan muat masuk kedalam blender untuk proses penghalusan. Wortel dipotong menggunakan pisau dengan ukuran 10-15 milimeter tiap potongannya.

\section{Penghalusan Wortel}

Penghalusan dilakukan untuk merubah bentuk wortel yang telah dipotong menjadi puree 
wortel. Penghalusan dilakukan menggunakan blender. Wortel yang telah dipotong dimasukkan kedalam blender dan ditambah air dengan perbandingan yang telah ditentukan, yaitu $3: 1 ; 1: 2$; dan $2: 1$. Setelah itu diblender dengan variasi waktu 150 detik, 210 detik, dan 270 detik sampai campuran wortel dan air menjadi puree.

\section{Engineering Properties Analysis}

Sifat enjiniring yang diukur berupa Viskositas, Warna, Densitas, Konduktivitas Termal, dan Total Padatan.

\section{Pengukuran Viskositas}

Pengukuran nilai viskositas puree wortel dilakukan menggunakan Viscometer (Brookfield DV-II+Pro). Sampel sebanyak $500 \mathrm{ml}$ dalam gelas beaker diletakkan pada alat viscometer. Kemudian nyalakan alat dan catat nilai pengukuran yang keluar pada layar lcd.

\section{Pengukuran Warna}

Pengukuran warna puree wortel menggunakan alat Color Reader (Minolta CR10). Sampel yang ada diletakkan pada petri dish sebelum pengukuran. Pengukuran dilakukan setelah mengkalibrasi alat dengan memindai warna standar yaitu kertas putih, kemudian dilanjutkan dengan memindai 3 titik acak pada permukaan sampel.

\section{Pengukuran Densitas \\ Pengukuran densitas dilakukan dengan mengukur berat gelas ukur menggunakan timbangan digital (ketelitian 0,01 gram). Kemudian menimbang sampel puree wortel yang dimasukkan kedalam gelas ukur.}

\section{Pengukuran Konduktivitas Termal}

Pengukuran konduktivitas termal pada puree wortel menggunakan alat Manual Thermal Analyzer KD2 Pro. Pengukuran dilakukan dengan meletakkan sensor yang dipasang pada sampel sebanyak $120 \mathrm{ml}$. Sensor yang digunakan yaitu sensor SH-1. Nilai pengukuran akan keluar pada layar Manual Thermal Analyzer KD2 Pro.

\section{Pengukuran Total Padatan}

Pengukuran total padatan pada puree wortel dilakukan dengan mengambil sampel sebanyak 5 gram dan dioven selama 5 jam dengan suhu $105^{\circ} \mathrm{C}$. Hasil pengovenan kemudian ditimbang dengan menggunakan timbangan analitik dengan ketelitian 0,01 gram.

\section{Analisis Data}

Data yang diperoleh dari penelitian kemudian diuji menggunakan Analysis of Variance (anova) dua arah. Uji anova bertujuan untuk mengetahui pengaruh dua factor perbandingan wortel dan air serta lama waktu penghalusan terhadap nilai sifat enjiniring puree wortel.

\section{Rancangan Percobaan}

Rancangan yang digunakan yaitu RAL (Rancangan Acak Lengkap) dengan menggunakan 2 faktor. Faktor pertama yaitu perbandingan wortel: air $(\mathrm{W} 1=3: 1 ; \mathrm{W} 2=1: 2$; $\mathrm{W} 3=2: 1)$. Faktor kedua yaitu waktu lama proses penghalusan menggunakan blender ( $\mathrm{T} 1=150$ detik; $\mathrm{T} 2=210$ detik; $\mathrm{T} 3=270$ detik). Dari 2 faktor tersebut akan diperoleh 9 kombinasi perlakuan yang masing-masing perlakuan dilakukan pengulangan sebanyak 3 kali.

\section{Metode Analisis}

Analisis data hasil penelitian ini dilakukan dengan menggunakan program Microsoft Excel dan SPSS. Analisis data menggunakan Uji ANOVA dua arah dengan taraf $\alpha 0,05$ dan uji lanjutan metode Tukey. Sebelum di analisis menggunakan uji ANOVA, data terlebih dulu di uji normalitasnya.

\section{HASIL DAN PEMBAHASAN}

\section{Viskositas}

Viskositas merupakan suatu gesekan yang terjadi antara lapisan-lapisan yang bersebelahan di dalam suatu fluida. Viskositas pada zat gas diakibatkan oleh tumbukan antar molekul-molekul gas, sedangkan viskositas pada zat cair terjadi akibat adanya gaya kohesi antar molekul-molekul zat cair (Giancoli, 2014). 


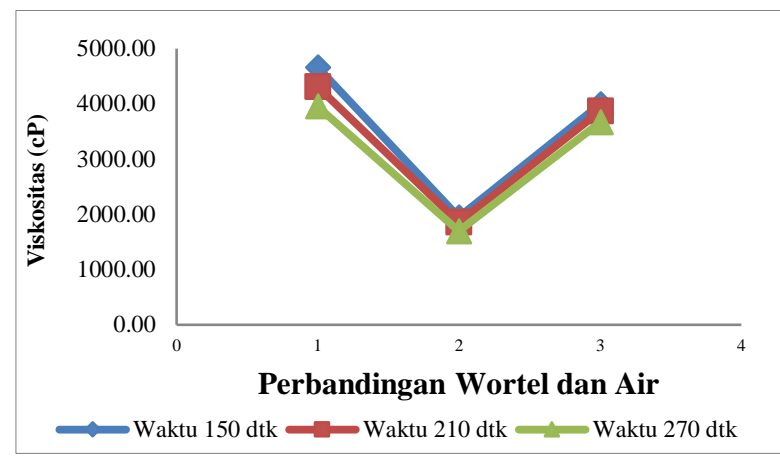

Gambar 1. Grafik viskositas

Berdasarkan hasil penelitian yang telah dilakukan, nilai viskositas yang di dapat berkisar antara 1697,78 cP sampai dengan 4661,44 cP. Nilai viskositas tertinggi terdapat pada perlakuan sampel W1t1 dengan perbandingan wortel dan air 3:1 serta lama penghalusan 150 detik. Sementara nilai viskositas terkecil terdapat pada perlakuan sampel W2t3 dengan perbandingan wortel dan air 1:2 serta lama waktu penghalusan 270 detik. Pada Gambar 1 menunjukkan perbedaan nilai viskositas puree wortel pada setiap kombinasi perlakuan. Perbedaan nilai viskositas tersebut disebabkan karena beda komposisi perbandingan wortel dan air. Semakin besar perbandingan wortel terhadap air maka nilai viskositas akan semakin besar karena kandungan solid pada wortel juga akan semakin banyak. Lama waktu penghalusan juga berpengaruh karena semakin lama wortel dan air di blender maka larutan puree tersebut akan semakin halus dan encer. Hal ini menyebabkan semakin lama waktu penghalusan maka nilai viskositasnya akan semakin kecil.

\section{Densitas}

Massa jenis atau densitas adalah pengukuran massa setiap satuan volume suatu benda. Semakin tinggi massa jenis benda tersebut, maka masa setiap volumenya juga akan semakin besar. Massa jenis rata-rata setiap benda merupakan total massa dibagi dengan total volumenya (Julianto, 2012).

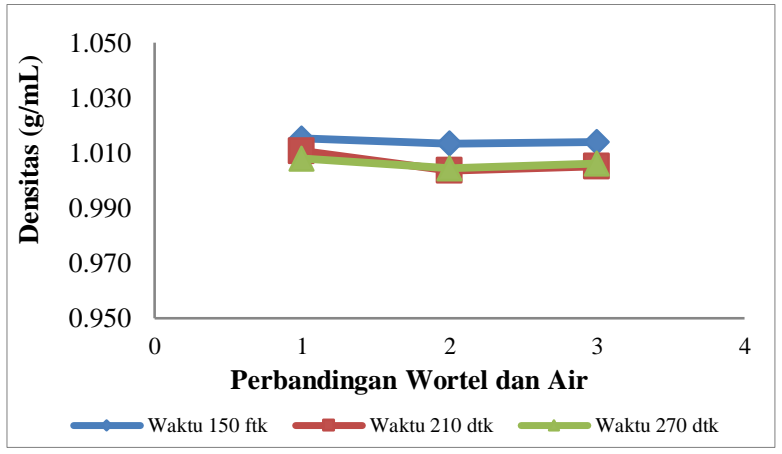

Gambar 2. Grafik densitas

Berdasarkan hasil penelitian yang telah dilakukan, nilai densitas berkisar antara 1,004 $\mathrm{g} / \mathrm{mL}$ sampai dengan $1,015 \mathrm{~g} / \mathrm{mL}$. Nilai densitas tertinggi didapat pada perlakuan sampel W1t1 dengan perbandingan wortel dan air 3:1 serta lama penghalusan 150 detik. Sedangkan nilai densitas terendah didapat pada perlakuan sampel W2t2 dan W2t3, dengan masing-masing perbandingan wortel dan air 1:2 serta lama penghalusan 210 detik dan 270 detik. Gambar 2 menunjukkan bahwa kombinasi perlakuan mempengaruhi nilai densitas puree wortel. Pada perlakuan perbedaan lama waktu penghalusan terjadi perbedaan, semakin lama waktu penghalusan makan semakin kecil nilai densitasnya. Hal ini karena semakin lama waktu penghalusan maka wortel akan semakin halus dan nantinya akan menjadi cair. Perbedaan perbandingan wortel dan air juga mempengaruhi nilai densitas. Semakin besar nilai perbandingan air maka nilai densitas akan semakin kecil. Hal ini karena semakin banyak wortel yang digunakan maka padatan terlarutnya akan semakin banyak dan mempengaruhi massa puree wortel sehingga nilai densitasnya akan besar, begitu juga sebaliknya jika perbandingan air lebih banyak dari wortel maka akan mengurangi kandungan padatan terlarut dalam puree sehingga massa puree wortel akan kecil dan nilai densitas juga akan kecil.

\section{Total Padatan}

Total padatan adalah jumlah padatan dari suatu produk atau padatan yang terlarut maupun tidak terlarut yang tersisa ketika air dalam suatu produk diuapkan (Standar Nasional Indonesia, 1992). Total padatan juga dapat diartikan sebagai komponen penyusun 
larutan berupa padatan terlarut maupun tidak terlarut dalam suatu bahan atau produk.

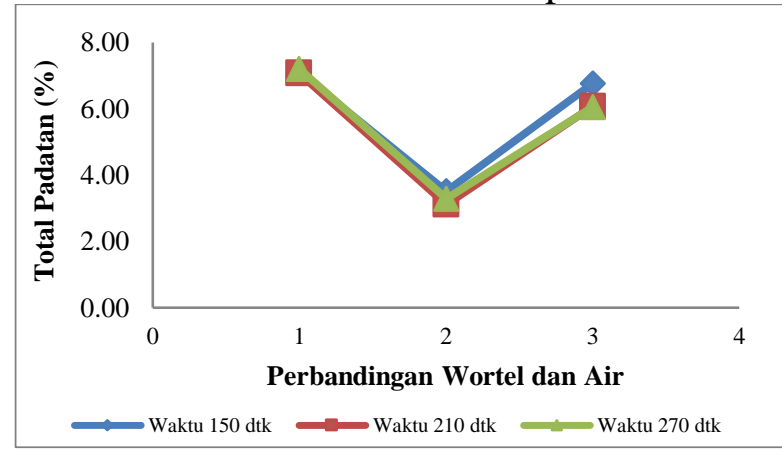

Gambar 3. Grafik total padatan

Berdasarkan hasil penelitian yang dilakukan, nilai total padatan puree wortel berkisar antara $3,11 \%$ sampai $7,20 \%$. Nilai tertinggi didapat dari perlakuan sampel W1t3 dengan perbandingan wortel dan air 3:1 serta waktu penghalusan selama 270 detik. Nilai terendah didapat pada perlakuan sampel W2t2 dengan perbandingan wortel dan air 1:2 serta lama penghalusan 210 detik. Gambar 3 menunjukkan bahwa perlakuan perbandingan wortel dan air berpengaruh terhadap nilai total padatan puree wortel. Semakin besar komposisi wortel maka nilai total padatan akan semakin besar. Hal ini disebabkan karena semakin banyak wortel dalam puree wortel maka kandungan padatan terlarutnya akan semakin banyak sehingga nilai total padatan dalam puree wortel juga akan semakin besar. Nilai total padatan berbanding lurus dengan nilai viskositas karena viskositas merupakan nilai gesekan terhadap padatan terlarut dalam suatu larutan. Hal ini menyebabkan semakin banyak total padatan terlarut dalam puree wortel maka semakin besar gesekan dalam larutan sehingga semakin besar nilai viskositas puree wortel.

\section{Warna}

\section{Indeks warna $L$}

Variable L menunjukkan tingkat kecerahan suatu produk dengan rentang nilai antara 0 (hitam) sampai dengan 100 (putih). Berdasarkan hasil penelitian yang dilakukan, nilai $\mathrm{L}$ dari puree wortel berkisar antara 34,33 sampai dengan 42,77. Nilai L tertinggi terdapat pada perlakuan sampel W1t1 dengan perbandingan wortel dan air 3:1 serta lama penghalusan 150 detik. Nilai L terendah terdapat pada perlakuan sampel $\mathrm{W} 2 \mathrm{t} 3$ dengan perbandingan wortel dan air 1:2 serta lama penghalusan 270 detik.

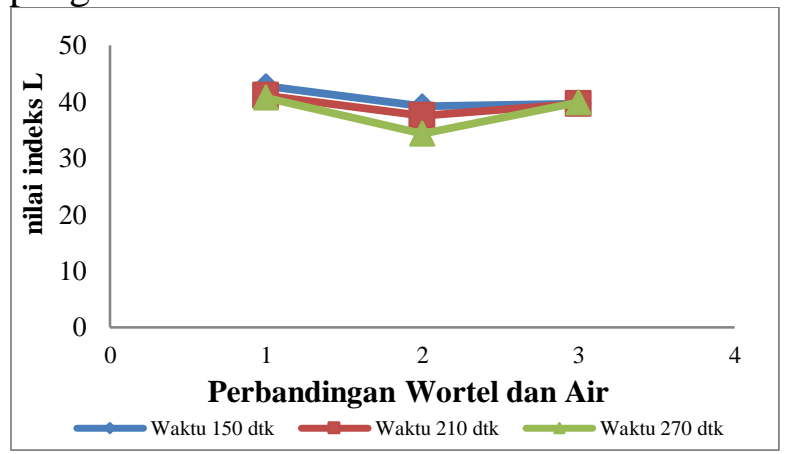

Gambar 4. Grafik indeks warna L

Gambar 4 menunjukkan bahwa nilai warna L akan semakin kecil jika perbandingan wortel dan air semakin kecil. Sesuai uji ANOVA bahwa perbandingan wortel dan air berpengaruh tidak nyata terhadap nilai L warna puree wortel. Hal ini karena semakin banyak wortel yang digunakan maka warna wortel akan lebih cerah dan dominan karena air yang digunakan sedikit. Nilai L kecil karena jika jumlah air semakin banyak maka warna asli wortel akan pudar akibat tercampur air sehingga warnanya pudar dan kecerahannya berkurang.

\section{Indeks warna a}

Variable nilai a pada pengukuran warna menunjukkan warna merah (+a) dan hijau (-a) dengan rentang nilai antara -80 sampai dengan +80 . Semakin nilai mendekati -80 maka warna bahan tersebut semakin hijau begitu juga sebaliknya jika nilai semakin mendekati 80 maka warna bahan akan semakin merah. Berdasarkan hasil penelitian yang telah dilakukan, nilai a puree wortel berkisar antara -1,06 sampai dengan 6,44. Nilai a tertinggi terdapat pada perlakuan sampel W1t3 dengan perbandingan wortel dan air 3:1 serta lama penghalusan 270 detik. Nilai a terendah terdapat pada perlakuan sampel W2t1 dengan perbandingan wortel dan air 1:2 serta lama penghalusan 150 detik. 


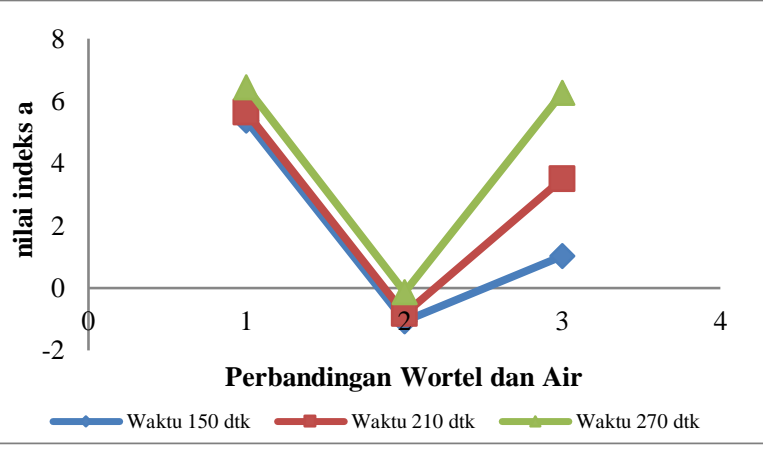

Gambar 5. Grafik indeks warna a

Gambar 5 menunjukkan semakin besar jumlah perbandingan wortel dan air maka nilai indeks warna merah $(+a)$ akan semakin tinggi. Hal ini karena indeks warna merah dipengaruhi oleh warna bahan baku wortel. Semakin banyak air yang digunakan maka indeks warna merah (+a) pada puree wortel akan semakin kecil karena warna akan semakin pucat jika banyak air yang digunakan.

\section{Indeks warna $b$}

Variabel $b$ pada pengukuran warna menunjukkan tingkat nilai kuning (+70) dan biru (-70). Semakin nilai mendekati -70 maka warna bahan akan semakin biru, sedangkan jika nilai mendekati +70 maka warna bahan akan semakin kuning. Berdasarkan hasil penelitian yang telah dilakukan, nilai $b$ dari puree wortel berkisar antara 12,65 sampai dengan 26,95. Nilai b tertinggi terdapat pada perlakuan sampel W1t3 dengan perbandingan wortel dan air 3:1 serta lama penghalusan 270 detik. Nilai $b$ terendah terdapat pada perlakuan sampel $\mathrm{W} 2 \mathrm{t} 1$ dengan perbandingan wortel dan air 1:2 serta lama penghalusan 150 detik.

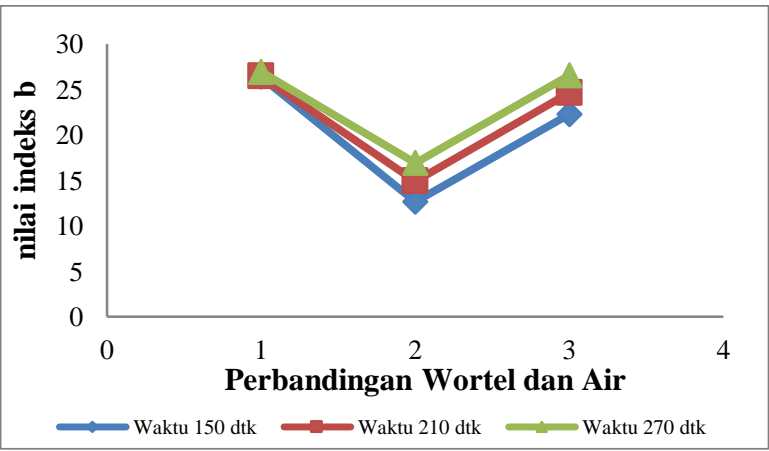

Gambar 6. Grafik indeks warna b
Gambar 6 menunjukkan perlakuan perbandingan wortel dan air berpengaruh terhadap nilai indeks warna kuning $(+b)$ puree wortel. Semakin banyak wortel yang digunakan maka semakin besar nilai indeks warna kuning $(+b)$ pada puree wortel. Hal ini disebabkan oleh warna bahan baku wortel yang cenderung orange kekuningan, sehingga jika kandungan air pada puree semakin banyak maka warna pada puree wortel akan semakin pucat.

Warna bahan baku wortel dipengaruhi dari umur wortel tersebut. Wortel yang masih muda umumnya berwarna orange pucat, wortel dengan umur panen optimal berwarna orange cerah sedangkan wortel yang sudah terlalu tua berwarna orange gelap. Wortel yang digunakan pada penelitian ini dibeli dari satu pedagang di pasar Kreongan tanpa didasari pada jenis varietas.

\section{Konduktivitas Termal}

Konduktivitas termal merupakan kemampuan suatu bahan dalam menghantarkan panas dalam sautu waktu tertentu yang diakibatkan adanya perbedaan suhu. Berdasarkan hasil penelitian yang telahh dilakukan, nilai konduktivitas termal puree wortel berkisar antara $0,577 \mathrm{~W} / \mathrm{m} . \mathrm{K}$ sampai dengan 0,682 $\mathrm{W} / \mathrm{m} . \mathrm{K}$. nilai konduktivitas tertinggi terdapat pada perlakuan sampel W1t1 dengan perbandingan wortel dan air 3:1 serta lama penghalusan 150 detik. Nilai konduktivitas termal terendah terdapat pada perlakuan sampel W2t3 dengan perbandingan wortel dan air 1:2 serta lama penghalusan 270 detik.

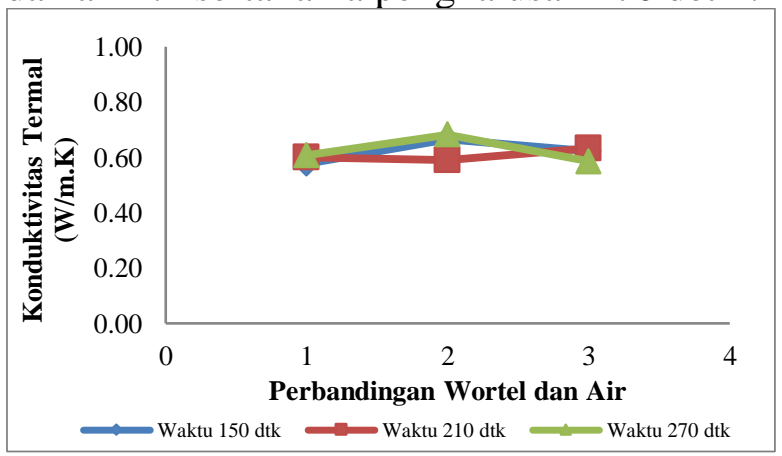

Gambar 7. Grafik Konduktivitas Termal

Gambar 7 menunjukkan perbandingan wortel dan air serta lama waktu penghalusan tidak mempengaruhi nilai konduktivitas 
termal, hal ini dapat dilihat dari grafik yang tidak terlalu berbeda pada Gambar 7. Hal ini karena konduktivitas termal suatu larutan lebih dipengaruhi oleh bahan pelarut serta suhu bahan dan suhu ruangan ketika dilakukan pengukuran.

\section{KESIMPULAN}

Pengukuran sifat enjiniring puree diperoleh hasil berturut-turut yaitu nilai viskositas berkisar antara 1697,78 cP sampai dengan $4661,44 \mathrm{cP}$. Nilai total padatan berkisar antara $3,11 \%$ sampai dengan $7,20 \%$. Nilai densitas berkisar antara $1,004 \mathrm{~g} / \mathrm{mL}$ sampai dengan $1,015 \mathrm{~g} / \mathrm{mL}$. Nilai indeks warna $\mathrm{L}$ berkisar antara 34,33 sampai dengan 42,77. Nilai indeks warna a berkisar antara -1,06 sampai dengan 6,44. Nilai indeks warna b berkisar antara 12,65 sampai dengan 26,95. Nilai konduktivitas termal berkisar antara 0,577 $\mathrm{W} / \mathrm{m} . \mathrm{K}$ sampai dengan $0,682 \mathrm{~W} / \mathrm{m} . \mathrm{K}$.

Perlakuan perbandingan wortel dan air memiliki hubungan berbanding lurus dengan nilai viskositas, total padatan, densitas, nilai indeks warna $\mathrm{L}$, a, dan b. Semakin banyak proporsi wortel pada larutan puree maka nilai viskositas, total padatan, densitas, nilai indeks warna L, a, dan b akan semakin naik. Sementara pada nilai konduktivitas termal tidak ada pengaruh dari perbandingan wortel dan air. Pada perlakuan lama waktu penghalusan tidak berpengaruh terhadap nilai total padatan, nilai indeks warna $L$, a, dan $b$. namun berpengaruh terhadap nilai densitas dan viskositas puree wortel. Semakin lama waktu penghalusan maka nilai viskositas dan densitas akan semakin besar.

\section{DAFTAR PUSTAKA}

Badan Pusat Statistik. (2017). Statistik Tanaman Sayuran dan Buah-buahan Semusim Indonesia 2017. Jakarta: Badan Pusat Statistik.

Giancoli, D.C. 2014. Fisika: Prinsip dan Aplikasi Jilid 1 Edisi 7. Jakarta: Erlangga
Julianto,

A. 2012 .

Densitas.

blogs.unpad.ac.id/ariejulianto/

2012/10/03/hello-world. [Diakses pada 8 Juli 2020]

Mehrir. (2012). Sejarah Wortel. Http;//Www.Kawungaten.Com/2012/11 /Sejarah Wortel.Html.[Diakses pada 18 April 2019]

Standar Nasional Indonesia, 1992. Cara Uji Makanan dan Minuman. Dewan Standarisasi Nasional. 